\title{
Nordmøre Grid Trial in Large Prawn Senegalese Fishery: Interest to Reduce By-catch not Evidenced
}

\author{
Ndiaga Thiam ${ }^{1, *}$, Fambaye Ngom Sow ${ }^{1}$, Massal Fall ${ }^{1}$, Yoland Plourde ${ }^{2}$, Modou Thiaw ${ }^{1}$, \\ Moustapha Dème ${ }^{1}$, Mor Sylla ${ }^{1}$, Babacar Faye ${ }^{3}$ \\ ${ }^{1}$ CRODT/ISRA, Site du Pôle de Recherches de Hann, Dakar, Sénégal \\ ${ }^{2}$ Halieutec/EPAQ, 167, La Grande-Allée Est, Grande Rivière, Québec, Canada \\ ${ }^{3}$ ENFM, Boulevard du Centenaire de la Commune de Dakar, Sénégal
}

Copyright $\mathrm{C} 2018$ by authors, all rights reserved. Authors agree that this article remains permanently open access under the terms of the Creative Commons Attribution License 4.0 International License

\begin{abstract}
Demersal shrimp fisheries, which are not very selective, generate significant discards and / or bycatch, generally composed of crustaceans, fish and molluscs of different size classes. As part of the implementation of the management plan for the deepwater shrimp Parapenaeus longirostris in Senegal, selectivity tests of the Nordmore device were conducted. Thus, three Nordmore grids characterized by different spacings between the bars $(24,28$ and $30 \mathrm{~mm}$ ) were tested on the experimental trawl in the Senegalese Economic Zone. Regardless of spacing, the Nordmore Grid completely removed large individuals from several species of commercial interest (John dory and Bearded brotula) or not (rays, sharks, etc.). Gamba shrimp loss analyzes indicate a significant difference $(\alpha<0.05)$ between the three spacer grids 24,28 and $30 \mathrm{~mm}$. Regardless of the type of grid, the amount of shrimp sorted per minute is larger for the experimental trawl; and this quantity increases with the spacing of the grid. The $30 \mathrm{~mm}$ grid stands out with percentages of gamba shrimp losses ranging from 3 to $20 \%$ with an average of $8 \%$; and a ratio of bycatch / gamba shrimp catch around $2.2 / 1$, below the world average for this type of fishery $(5 / 1)$.
\end{abstract}

Keywords Nordmøre Grid, Bycatch, Selectivity, Parapenaeus Longirostris, Senegal

\section{Introduction}

The ecosystem approach to fisheries has to prevent bycatch and discard for their impact on trophic web and habitat (Bellido et al. 2001) as well as their economic impact on whole fisheries (Pascoe and Revill, 2004). The sustainability of marine resource fisheries in Senegalese water is threatened by shrimp trawl. Deep demersal resources of Senegal contain many crustacean, fish and marine mollusc species, sustained by the nutrient rich cold water from Canary Current East Border upwelling system (Ndoye et al., 2014; Faye, 2015). These targeted species are living at depth ranging from 150 to $1000 \mathrm{~m}$ where they are mostly exploited by boats targeting shrimp and hake or by some seldom crabbers. After fish stocks overexploitation shrimp fishing became widespread and is a major marine resource for many coastal countries of West Africa, including Senegal (Thiaw et al. 2009). Shrimp trawlers essentially target large prawns Parapenaeus longirostris and striped red shrimps Aristeus varidens. However, the fishing method used to catch shrimp is one of the less selective (Ambrose et al. 2005), contributing for more than one quarter of accessory catches (1.9 million tons) observed in world fisheries (Kelleher 2005). The ratio "accessory catches vs. target species" observed for the shrimp is 5:1 (Alverson et al. 1994; Ambrose et al. 2012). In terms of fisheries sustainability, Senegalese fisheries industry has to improve the selectivity of their trawls (Eayrs, 2007). Alternatively to Square mesh netting (Mbye, 2005), selectivity system used by the Direction of Marine Fisheries of Senegal (Senegalese acronym: DPM) is the Nordmøre grid already used in Nigeria (Ambrose and Lebo 2009), which is a mechanical system of sorting according to organisms size, removing individuals larger than the spacing between bars. To our knowledge this was the first time that the Nordmøre grid has been tested in Senegalese shrimp fishery. The system has been widely used since several decades and is well described in Isaksen et al. (1992). Experiences in different fisheries have shown that the grid could generate great reductions in bycatch from 60 to $90 \%$ (Broadhurst, 2000) with a loss of shrimp of about $5 \%$ (Isaksen et al. 1992), which is considered to be acceptable. Originally developed in Norway at the end of the 1980s for the boreal shrimp (Pandalus borealis) (Isaksen et al. 1992), Nordmøre grids showed excellent results and were used for this fishery in early 1990's (Broadhurst 2000). The aim of this work was to test and evaluate the efficiency of the 
Nordmøre grid (Silva et al. 2012) in deep shrimp fishery of large prawns Parapenaeus longirostris in Senegal in the field in collaboration with the professional i.e. under commercial conditions (real condition), before to propose them this kind of gear.

\section{Materials \& Methods}

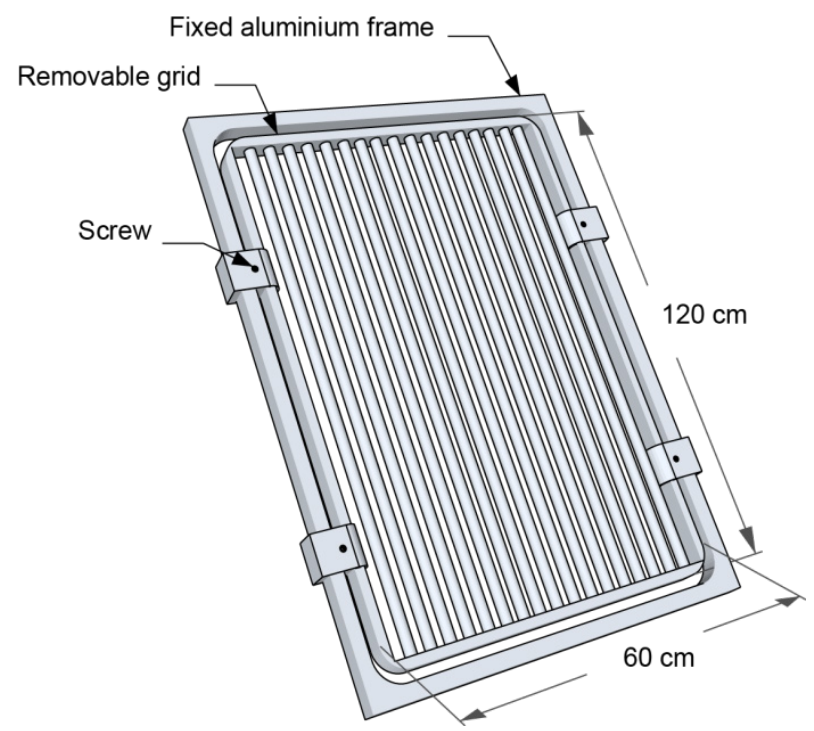

Figure 1. Fixing system of Nordmøre grids $(20,25$ and $28 \mathrm{~mm})$ easily interchangeable within the fixed aluminium frame, equipping the Florida rigging experimental trawl.

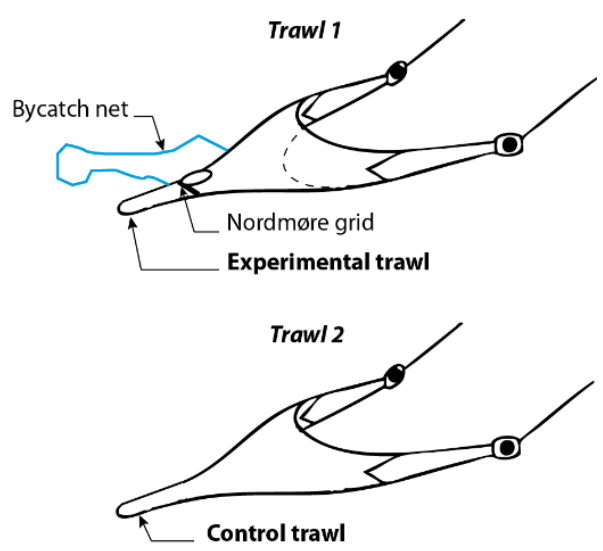

Figure 2. Experimental design of the florida rigging during experiments selectivity of deep shrimp fishery (Parapenaeus longirostris) in Senegal. Experimental trawl is equipped with the Nordmøre grid and the Bycatch net rejected by the Nordmøre grid. Unchanged trawl is the control.

Sea trials were conducted by scientists from the Centre de Recherches Océanographiques de Dakar Thiaroye (CRODT, Senegal) in collaboration with experts from the National School of Fisheries and Aquaculture of Québec (EPAQ, Québec, Canada). Sea trials have been held in October 2015 onboard the commercial ship HISPASEN IV from the Spanish - Senegalese armament (HISPASEN) in Senegal. The commercial boat was 34.34 meters and 240 barrels equipped with Florida pole rigging. One of the two trawls was modified by adding a section before the codend. This section contained the Nordmøre (Graham 2003; Fonseca et al., 2005; Silva et al., 2012) selectivity system and the trawl was hereafter called "experimental" trawl. A net of the same mesh as the bottom of the trawl was placed at the exit of the selectivity system to retain all taken apart by the grid and this net was called "bycatch" net. Three Nordmøre grids characterized by spacing differences between bars $(24,28$ and $30 \mathrm{~mm})$ were tested on the experimental trawl. Spacing between bars of the three grids was determined on the basis of the shrimp Parapenaeus longirostris biometric data (Thiam and Fall, 2010). A permanent framework (Figure 1) was installed with a tilt angle of $45^{\circ}$ (Isaksen et al. 1992) within one of the two trawls (experimental trawl) of the Florida rigging. The framework facilitated grids exchange during experiments. Nordmøre grid and the extension section of the trawl with its permanent framework were designed and manufactured by Senegal. The other trawl of the Florida rigging has not been modified and was considered as the "control" trawl (Figure 2).

The methodological approach has two phases: a pre-test phase and an experimental phase.

During the first pre-test phase, it was planned to conduct 3 tows with the 2 trawls of the Florida rig, to ensure the proper functioning of the device in place. These features were to allow adjustments to the device.

During the second experimental phase, it was decided to make 7 trawling operations with each type of grid in order to note the 2 that offer less loss of gamba shrimp. These two types of grid were retained for the rest of the mission. These are the space grids $28 \mathrm{~mm}$ and $30 \mathrm{~mm}$

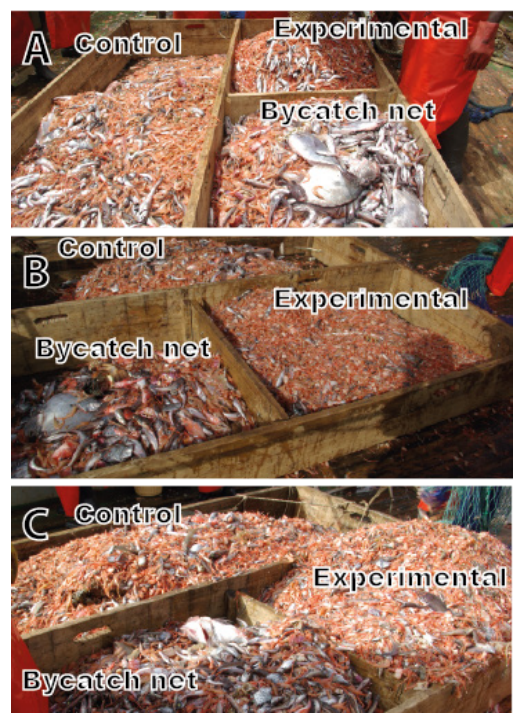

Figure 3. Removable box Photographs allowing separation between the bycatch net, the experimental trawl and the control trawl catches. Photographs during experiments with 24 (A), 28 (B) and $30 \mathrm{~mm}$ (C) Nordmøre grids.

A total of 33 hauls were performed: 7 hauls with the 24 $\mathrm{mm}$ grid, 14 with the $28 \mathrm{~mm}$ grid and 12 with the $30 \mathrm{~mm}$ 
grid. Hauls lasted from 1.30 to 2.5 hours. Trawl depth mean was 250 meters. For each haul, trawl nets have been emptied in separate wood compartments on the deck (Figure 3). In each compartment, a minimum of $15 \%$ of the total catches was sampled, sorted by species, counted and weighed. Specific mass fractions were then extrapolated to the whole catch of each compartment. After sampling, the ship's crew sorted catches in the different compartments and the sorting time was recorded.

In both the control and experimental trawls, the number of broken shrimp and the amount of intact shrimp were determined. For each fishing haul, a sample of at least 50 individuals of the deep-water shrimp Parapenaeus longirostris was taken randomly for the measurement of cephalothoracic length and caliber width (the largest length of shrimp cephalothorax in the transversal direction) by means of caliper millimeter-scale accuracy.

Statistical analyses were performed using Statistica software version 7.0 (StatSoft, USA), with $\alpha=0.05$. Normality of the data was examined using the
Kolmogorov-Smirnov test. Homoscedasticity was tested with the Brown-Forsyte test (Zar, 1999). Data were tested using one- or two- way analysis of variance. For subsequent multiple comparisons, Tukey tests or Tukey tests for unequal $n$ were performed when appropriate. The Games \& Howell test was used when heteroscedasticity was observed (Soka and Rohlf 1995).

\section{Results and Discussion}

\section{Results}

Overall proportions of gamba and bycatch in control and experimental trawls

For the same grid, the ratio of bycatch (BC) to gamba shrimp (CG) is always higher for the control trawl compared to the experimental trawl (Table 1). By considering the experimental trawl, as the spacing of the grid increases, the ratio decreases.

Table 1. Proportions of Parapenaeus longirostris and bycath in the experimental trawl (Exp. Trawl, bycatch net excluded) and control (Control trawl) during the tests with grids 24,28 and $30 \mathrm{~mm}$.

\begin{tabular}{|c|c|c|}
\hline Type of trawl & Control & Experimental \\
\hline Grids & Ratio $=$ BC/CG & Ratio $=$ BC/CG \\
\hline $24 \mathrm{~mm}$ & $19 / 1$ & $9,8 / 1$ \\
\hline $28 \mathrm{~mm}$ & $10,1 / 1$ & $4,3 / 1$ \\
\hline $30 \mathrm{~mm}$ & $6,2 / 1$ & $2,2 / 1$ \\
\hline
\end{tabular}

Table 2. Bycatch elimination rate by spacer grid $24 \mathrm{~mm}$

\begin{tabular}{|c|c|c|c|}
\hline Species & $\begin{array}{c}\text { Experimental } \\
\text { Trawl } \\
\end{array}$ & $\begin{array}{c}\text { Bycatch } \\
\text { net }\end{array}$ & $\begin{array}{c}\text { Elimination } \\
\text { rate }(\%)\end{array}$ \\
\hline Ariomma bondi & 0,15 & 0,10 & 40 \\
\hline Bathynectes piperitus & 0,60 & 0,98 & 62 \\
\hline Bembrops heuterurus & 2,14 & 1,48 & 41 \\
\hline Brotula barbata & 0,00 & 3,33 & 100 \\
\hline Calappa sp & 0,34 & 1,62 & 83 \\
\hline Centrophorus uyato & 0,00 & 1,05 & 100 \\
\hline Chascanopsetta lugubris & 0,13 & 0,80 & 86 \\
\hline Chlorophthalmus atlanticus & 204,10 & 92,90 & 31 \\
\hline Coelorynchus braueri & 24,06 & 19,07 & 44 \\
\hline Coelorynchus coelorynchus & 0,00 & 1,43 & 100 \\
\hline Dicologoglossa cuneata & 0,68 & 1,79 & 72 \\
\hline Epigonus telescopus & 0,00 & 0,09 & 100 \\
\hline Etmopterus $s p$ & 0,10 & 0,00 & 0 \\
\hline Munidae & 320,03 & 132,59 & 29 \\
\hline Galeus polli & 6,77 & 9,95 & 60 \\
\hline
\end{tabular}




\begin{tabular}{|c|c|c|c|}
\hline Gephyroberyx darwinii & 0,00 & 0,79 & 100 \\
\hline Helicolenus dactylopterus & 1,80 & 9,06 & 83 \\
\hline Holoturie (Echinoderme) & 0,10 & 0,00 & 0 \\
\hline Hypoclidonia bella & 0,00 & 0,10 & 100 \\
\hline Laemonema laureysi & 28,33 & 4,54 & 14 \\
\hline Lophiodes kempii & 19,19 & 54,00 & 74 \\
\hline Malacocephalus sp & 51,54 & 142,59 & 73 \\
\hline Méduses & 0,00 & 1,59 & 100 \\
\hline Merluccius sp & 1,64 & 16,90 & 91 \\
\hline Microchirus boscanion & 0,54 & 0,00 & 0 \\
\hline Myctophidae & 3,30 & 1,10 & 25 \\
\hline Mystriophis rostellatus & 2,65 & 0,55 & 17 \\
\hline Octopus vulgaris & 0,35 & 0,00 & 0 \\
\hline Ophichtyidae & 0,33 & 1,18 & 78 \\
\hline Paramola cuvieri & 0,00 & 32,02 & 100 \\
\hline Parapeaneus longirostris & 29,47 & 6,66 & 18 \\
\hline Parasidus fraserbruneri & 4,44 & 0,95 & 18 \\
\hline Peristedion cataphratum & 0,30 & 0,33 & 52 \\
\hline Plesionika martia & 14,65 & 0,34 & 2 \\
\hline Pontinus kuhlii & 4,84 & 22,56 & 82 \\
\hline Octopus sp & 8,64 & 6,23 & 42 \\
\hline Pterothrissus belloci & 0,18 & 2,21 & 92 \\
\hline Raja straeleini & 1,48 & 23,78 & 94 \\
\hline Scylliorhinus canicula & 0,00 & 8,44 & 100 \\
\hline Sepia officinalis & 14,43 & 15,69 & 52 \\
\hline Solenocera africana & 0,00 & 0,08 & 100 \\
\hline Sphoeroides pachygaster & 0,00 & 2,26 & 100 \\
\hline Synagrops microlepsis & 120,75 & 47,39 & 28 \\
\hline Synchiropus phaeton & 0,09 & 0,10 & 53 \\
\hline Todarospsis eblanae & 7,17 & 8,92 & 55 \\
\hline Torpedo fuscomaculata & 0,00 & 4,24 & 100 \\
\hline Torpedo marmorata & 0,00 & 1,35 & 100 \\
\hline Torpedo nobliana & 0,00 & 1,10 & 100 \\
\hline Trigla lyra & 0,14 & 7,05 & 98 \\
\hline Zenopsis conchifer & 0,00 & 244,70 & 100 \\
\hline Total & 845,98 & 929,32 & 52 \\
\hline
\end{tabular}


Table 3. Bycatch elimination rate by spacer grid $28 \mathrm{~mm}$.

\begin{tabular}{|c|c|c|c|}
\hline Species & Experimental trawl & Bycatch net & Elimination rate (\%) \\
\hline Ariomma bondi & 0,05 & 0,37 & 88 \\
\hline Aristeus varidens & 0,55 & 0,00 & 0 \\
\hline Aulopus cadenati & 0,11 & 0,00 & 0 \\
\hline Bathynectes piperitus & 3,29 & 3,41 & 51 \\
\hline Bembrops heuterurus & 2,02 & 2,23 & 52 \\
\hline Bernard l'hermite & 0,10 & 0,00 & 0 \\
\hline Beryx splendens & 0,00 & 0,25 & 100 \\
\hline Brotula barbata & 0,26 & 6,26 & 96 \\
\hline Calappa sp & 1,09 & 11,94 & 92 \\
\hline Centrolophus niger & 0,00 & 0,35 & 100 \\
\hline Chlorophthalmus atlanticus & 251,14 & 61,84 & 20 \\
\hline Coelorynchus braueri & 13,12 & 6,80 & 34 \\
\hline Crevette sp & 2,50 & 0,00 & 0 \\
\hline Cytopsis roseus & 0,00 & 0,07 & 100 \\
\hline Dicologoglossa cuneata & 1,34 & 1,61 & 54 \\
\hline Epigonus telescopus & 0,00 & 0,40 & 100 \\
\hline Gadella imberbis & 2,25 & 2,80 & 55 \\
\hline Munidae & 20,26 & 0,00 & 0 \\
\hline Galeus polli & 0,18 & 0,15 & 45 \\
\hline Gephyroberyx darwinii & 0,05 & 0,91 & 95 \\
\hline Glyphus marsupialis & 3,95 & 0,81 & 17 \\
\hline Helicolenus dactylopterus & 0,53 & 5,50 & 91 \\
\hline Himantolophus groenlandus & 0,00 & 2,03 & 100 \\
\hline Hoplosthetus cadenati & 0,00 & 0,54 & 100 \\
\hline Hypoclidonia bella & 0,00 & 7,12 & 100 \\
\hline Laemonema laureysi & 22,11 & 15,65 & 41 \\
\hline Lophiodes kempii & 9,84 & 19,80 & 67 \\
\hline Malacocephalus sp & 18,94 & 30,96 & 62 \\
\hline Méduses & 111,77 & 108,16 & 49 \\
\hline Merluccius sp & 19,86 & 105,69 & 84 \\
\hline Microchirus boscanion & 0,10 & 0,00 & 0 \\
\hline Myctophidae & 4,67 & 0,39 & 8 \\
\hline Mystriophis rostellatus & 3,07 & 8,80 & 74 \\
\hline Ophichtydae & 14,71 & 0,02 & 0 \\
\hline Paramola cuvieri & 0,00 & 0,66 & 100 \\
\hline Parasidus fraserbruneri & 2,69 & 0,25 & 9 \\
\hline Peristedion cataphratum & 0,00 & 0,10 & 100 \\
\hline
\end{tabular}




\begin{tabular}{|c|c|c|c|}
\hline Phosichthys argenteus & 0,18 & 0,08 & 31 \\
\hline Physiculus huloti & 0,00 & 3,62 & 100 \\
\hline Plesionika martia & 29,44 & 0,91 & 3 \\
\hline Setarches guntheri & 0,00 & 0,12 & 100 \\
\hline Pontinus kuhlii & 4,20 & 29,72 & 88 \\
\hline Octopus sp & 2,20 & 0,16 & 7 \\
\hline Pterothrissus belloci & 2,98 & 23,62 & 89 \\
\hline Raja straeleini & 0,55 & 0,56 & 50 \\
\hline Ruvettus pretiosus & 0,00 & 2,33 & 100 \\
\hline Sepia officinalis & 0,68 & 0,92 & 58 \\
\hline Solenocera africanus & 31,61 & 2,28 & 7 \\
\hline Sphoeroides pachygaster & 0,00 & 1,55 & 100 \\
\hline Stomias boa & 0,00 & 0,02 & 100 \\
\hline Synagrops microlepsis & 254,78 & 9,43 & 4 \\
\hline Synchiropus phaeton & 0,03 & 0,00 & 0 \\
\hline Todarospsis eblanae & 19,82 & 17,11 & 46 \\
\hline Trachipterus trachypterus & 0,20 & 0,00 & 0 \\
\hline Trichiurus lepterus & 1,27 & 0,67 & 35 \\
\hline Lepidopus caudatus & 0,00 & 0,08 & 100 \\
\hline Species & Experimental trawl & Bycatch net & Elimination rate (\%) \\
\hline Trigla lyra & 0,27 & 1,01 & 79 \\
\hline Yarella blackfordi & 0,00 & 0,03 & 100 \\
\hline Zenopsis conchifer & 0,00 & 413,39 & 100 \\
\hline Total & 858,76 & 913,48 & 52 \\
\hline
\end{tabular}

Table 4. Bycatch elimination rate by spacer grid $30 \mathrm{~mm}$.

\begin{tabular}{|c|c|c|c|}
\hline Species & Experimental trawl & Bycatch net & Elimination rate (\%) \\
\hline Ariomma bondi & 0,39 & 0,00 & 15 \\
\hline Bathynectes piperitus & 2,55 & 0,45 & 76 \\
\hline Bembrops heuterurus & 0,20 & 0,62 & 100 \\
\hline Bernard l'hermite & 0,00 & 0,15 & 100 \\
\hline Brama brama & 0,00 & 0,10 & 100 \\
\hline Brotula barbata & 0,00 & 9,80 & 100 \\
\hline Calappa rubruguttata & 0,00 & 0,10 & 73 \\
\hline Calappa sp & 1,16 & 0,22 & 81 \\
\hline Chascanopsetta lugubris & 0,05 & 0,00 & 0 \\
\hline Chaunax pictus & 0,10 & 11,48 & 6 \\
\hline Chlorophthalmus atlanticus & 194,05 & 2,88 & 41 \\
\hline Coelorynchus braueri & 4,23 & 0,25 & 81 \\
\hline Cytopsis roseus & 0,06 & 0,10 & 100 \\
\hline Dentex macrophthalmus & 0,00 & 0,40 & 56 \\
\hline Dicologoglossa cuneata & 0,32 & & 73 \\
\hline
\end{tabular}




\begin{tabular}{|c|c|c|c|}
\hline Epigonus telescopus & 0,00 & 2,38 & 100 \\
\hline Euthynnus alluteratus & 0,00 & 1,83 & 100 \\
\hline Gadella imberbis & 3,28 & 2,95 & 47 \\
\hline Munidae & 48,17 & 1,33 & 3 \\
\hline Galeus polli & 0,04 & 0,00 & 0 \\
\hline Gephyroberyx darwini & 0,64 & 6,69 & 91 \\
\hline Glyphus marsupialis & 1,42 & 0,00 & 0 \\
\hline Helicolenus dactylopterus & 1,14 & 1,68 & 60 \\
\hline Holoturie & 0,00 & 0,12 & 100 \\
\hline Laemonema laureysi & 14,90 & 3,15 & 17 \\
\hline Lophiodes kempii & 10,68 & 8,33 & 44 \\
\hline Malacocephalus sp & 12,65 & 14,32 & 53 \\
\hline Méduses & 29,58 & 139,68 & 83 \\
\hline Merluccius sp & 39,01 & 51,50 & 57 \\
\hline Microchirus boscanion & 0,03 & 0,20 & 87 \\
\hline Myctophidae & 4,72 & 0,29 & 6 \\
\hline Mystriophis rostellatus & 0,88 & 2,65 & 75 \\
\hline Octopus vulgaris & 2,12 & 0,00 & 0 \\
\hline Ophichtydae & 7,35 & 0,22 & 3 \\
\hline Palinurus mauritanicus & 0,00 & 2,00 & 100 \\
\hline Paramola cuvieri & 0,00 & 0,24 & 100 \\
\hline Parapeaneus longirostris & 229,90 & 17,62 & 7 \\
\hline Parasidus fraserbruneri & 5,46 & 0,34 & 6 \\
\hline Phosichthys argenteus & 0,05 & 0,00 & 0 \\
\hline Plesionika martia & 26,92 & 0,00 & 0 \\
\hline Setarches guntheri & 0,00 & 0,43 & 100 \\
\hline Pontinus kuhlii & 2,46 & 2,85 & 54 \\
\hline Octopus sp & 2,69 & 0,72 & 21 \\
\hline Pterothrissus belloci & 2,65 & 3,88 & 59 \\
\hline Raja straeleini & 0,23 & 0,00 & 0 \\
\hline Ruvettus pretiosus & 0,00 & 0,75 & 100 \\
\hline Scorpaena sp & 0,02 & 0,00 & 0 \\
\hline Scorpaena stephanica & 0,00 & 1,06 & 100 \\
\hline Scylliorhinus canicula & 0,41 & 1,54 & 79 \\
\hline Sepia officinalis & 0,40 & 0,06 & 13 \\
\hline Species & Experimental trawl & Bycatch net & Elimination rate (\%) \\
\hline Solenocera africana & 9,39 & 0,24 & 2 \\
\hline Squilla mantis & 0,02 & 0,00 & 0 \\
\hline Stomias boa & 0,08 & 0,00 & 0 \\
\hline Synagrops microlepsis & 51,75 & 4,72 & 8 \\
\hline Synchiropus phaeton & 0,04 & 0,00 & 0 \\
\hline Todarospsis eblanae & 17,12 & 13,69 & 44 \\
\hline Trichiurus lepterus & 0,00 & 0,71 & 100 \\
\hline Trigla lyra & 0,14 & 0,29 & 67 \\
\hline Zenopsis conchifer & 1,16 & 172,11 & 99 \\
\hline Total & 500,69 & 472,70 & 49 \\
\hline
\end{tabular}


Table 5. Total weight (in $\mathrm{kg}$ ) of commercial shrimp caught during trawl hauls and percentage of shrimp discarded by 3 different Nordmøre grids i.e. 24, 28 and $30 \mathrm{~mm}$. Experimental trawl (Exp. Trawl) was equipped with the sorting device and the by-catch net was mounted at the opening of the device to collect discarded animals.

\begin{tabular}{|c|c|c|c|c|}
\hline \multirow[b]{2}{*}{ Grid } & \multirow[b]{2}{*}{ Haul } & \multicolumn{2}{|c|}{ Total weight of commercial shrimp caught $(\mathrm{kg})$} & \multirow[b]{2}{*}{$\%$ discard } \\
\hline & & $\begin{array}{c}\text { Experimental } \\
\text { trawl }\end{array}$ & $\begin{array}{c}\text { Bycatch } \\
\text { net }\end{array}$ & \\
\hline \multirow{6}{*}{$24 \mathrm{~mm}$} & 1 & 1,73 & 0,35 & 17 \\
\hline & 2 & 0,2 & 0,15 & 43 \\
\hline & 3 & 8,87 & 2,78 & 24 \\
\hline & 4 & 4,75 & 1,42 & 23 \\
\hline & 6 & 8,03 & 0,91 & 10 \\
\hline & 7 & 5,89 & 1,05 & 15 \\
\hline Total $24 \mathrm{~mm}$ & & 29,47 & 6,66 & 18 \\
\hline \multirow{14}{*}{$28 \mathrm{~mm}$} & 8 & 14,56 & 1,38 & 9 \\
\hline & 9 & 15,07 & 1,48 & 9 \\
\hline & 10 & 8,12 & 0,68 & 8 \\
\hline & 11 & 32 & 9,02 & 22 \\
\hline & 12 & 22,32 & 3,46 & 13 \\
\hline & 13 & 12,6 & 3,18 & 20 \\
\hline & 14 & 24,1 & 2,69 & 10 \\
\hline & 15 & 9,5 & 3,53 & 27 \\
\hline & 27 & 19,23 & 3,74 & 16 \\
\hline & 28 & 15,24 & 2,92 & 16 \\
\hline & 29 & 10,94 & 2,98 & 21 \\
\hline & 30 & 7,24 & 2,14 & 23 \\
\hline & 31 & 8,82 & 2,7 & 23 \\
\hline & 32 & 5,17 & 0,135 & 3 \\
\hline Total $28 \mathrm{~mm}$ & & 204,91 & 40,035 & 16 \\
\hline \multirow{12}{*}{$30 \mathrm{~mm}$} & 16 & 51,12 & 4,02 & 7 \\
\hline & 17 & 30 & 1,05 & 3 \\
\hline & 18 & 22,8 & 0,95 & 4 \\
\hline & 19 & 28,04 & 0,75 & 3 \\
\hline & 20 & 10,32 & 0,86 & 8 \\
\hline & 21 & 16,57 & 2,35 & 12 \\
\hline & 22 & 12,38 & 1,11 & 8 \\
\hline & 23 & 13,42 & 3,36 & 20 \\
\hline & 24 & 15,6 & 1,1 & 7 \\
\hline & 25 & 4,87 & 0,45 & 8 \\
\hline & 26 & 7,15 & 0,87 & 11 \\
\hline & 33 & 2,95 & 0,75 & 20 \\
\hline Total $30 \mathrm{~mm}$ & & 215,22 & 17,62 & 8 \\
\hline
\end{tabular}


Table 6. Minimum, maximum and modal sizes (in mm) of the Parapenaeus longirostris gamba following the trawl and grid.

\begin{tabular}{|c|c|c|c|c|c|c|c|}
\hline & & \multicolumn{3}{|c|}{ Experimlental trawl } & \multicolumn{3}{c|}{ Control trawl } \\
\hline \multirow{2}{*}{ Grids } & Size & Min. & Max. & Mode & Min. & Max. & Mode \\
\hline \multirow{2}{*}{$24 \mathbf{~ m m}$} & LCT & 15 & 28 & 20 & 16 & 30 & 23 et 24 \\
\cline { 2 - 8 } & Cal. & 5 & 11 & 7 & 5 & 13 & 7 \\
\hline \multirow{2}{*}{$\mathbf{2 8} \mathbf{~ m m}$} & LCT & 8 & 37 & 25 & 20 & 73 & 14 \\
\cline { 2 - 8 } & Cal. & 7 & 14 & 11 & 18 & 34 & 26 \\
\hline $\mathbf{3 0} \mathbf{~ m m}$ & LCT & 18 & 37 & 24 & 7 & 16 & 11 \\
\hline
\end{tabular}

\section{Bycatch Elimination Rate}

The types of grids tested $(24,28$ and $30 \mathrm{~mm})$ have completely eliminated $(100 \%$ discards $)$ commercial species such as broth (Brotula barbata) and Saint-Pierre (Zenopsis conchifer). Other non-commercial species that play a very important role in the food webs of marine ecosystems, such as Centrolophus niger, Centrophorus uyato, Epigonus telescopus, Hypoclidonia bella, Paramola cuvieri, Setarches guntheri and Sphoeroides pachygaster are also eliminated $100 \%$ by the Nordmore grid (Tables 2, 3 and 4). A discard less than $100 \%$ is explained by the presence of small individuals able to pass between the bars of the grid, as for example the small individuals of hake Merluccius sp (Merluccius senegalensis and Merluccius polli) presenting an oscillating elimination rate $91 \%$ with the grid $24 \mathrm{~mm}$ at $57 \%$ with the grid $30 \mathrm{~mm}$ passing through $84 \%$ with the grid $28 \mathrm{~mm}$ (Tables 2, 3 and 4 ). The small individuals of this taxon retained in the experimental trawl had an average total length of $18 \pm 2.2 \mathrm{~cm}$ against 27 $\pm 3.3 \mathrm{~cm}$ for the individuals separated by the different grids.

\section{Proportions of Gamba Shrimp Loss}

Gamba shrimp loss analyzes, that is the ratio of the weight of shrimp gamba in the bycatch net to the weight of the shrimp in the experimental trawl including the bycatch net, indicate a significant difference $(\alpha<0.05)$ between the three spacer grids 24,28 and $30 \mathrm{~mm}$ :

- $\quad$ The $24 \mathrm{~mm}$ grid rejected $18 \%$ of shrimp on average, with minimum and maximum values of 10 and $43 \%$ respectively.

- The $28 \mathrm{~mm}$ grid had an average rejection of $16 \%$ and minimum and maximum values of 3 and $27 \%$, respectively.

- $\quad$ The $30 \mathrm{~mm}$ grid generated an average spread of $8 \%$ and minimum and maximum values of 3 and $20 \%$ respectively (Table 5).

It can be noted that the rate of loss of shrimp gamba is lower with the grid of $30 \mathrm{~mm}$.

\section{Size Frequencies}

With respect to the size (cephalothoracic length / LCT and caliber width / CAL) of the gamba, regardless of the type of grid, no significant difference was observed between the control trawl and the experimental trawl. However, modal size is often more important for the control trawl (Table 6, Figure 4) 

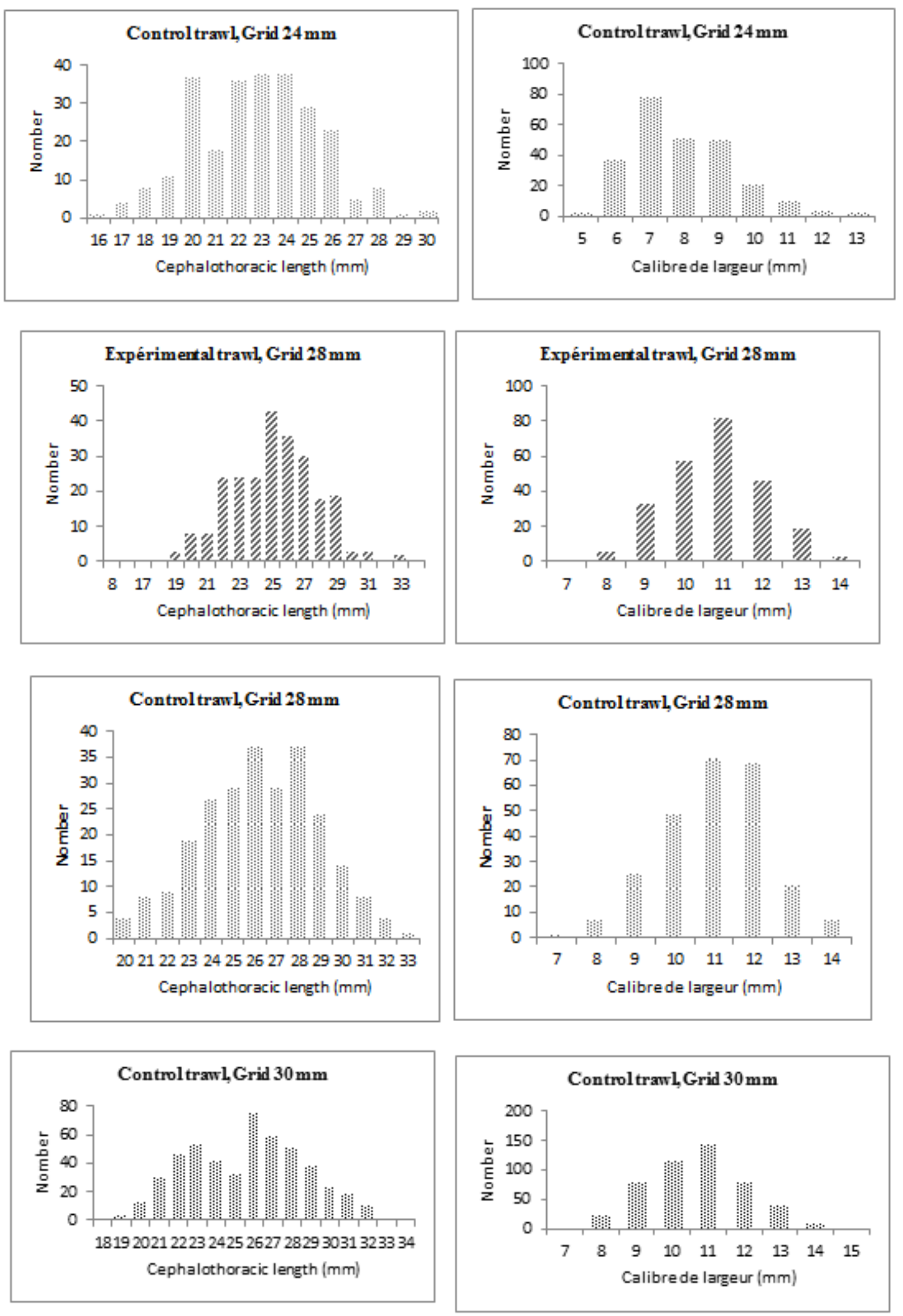

Figure 4. Size frequencies of cephalo thoracic (LCT - in $\mathrm{mm}$ ) and size gauge (mm) of shrimps caught in control and experimental trawls with Nordmore grids of 24,28 and $30 \mathrm{~mm}$. 


\section{Duration of Sorting}

For the $24 \mathrm{~mm}$ and $28 \mathrm{~mm}$ grates, the quantity of shrimp sorted per minute is not significantly different between the control trawl and the experimental trawl $(\alpha=0.22$, thus greater than 0.05 for the grid $24 \mathrm{~m} ; \alpha=0.93$ in the case of grid $28 \mathrm{~mm}$ ). On the other hand, a significant difference in the amount of sorted shrimp is noted between the control trawl and the experimental trawl $(\alpha=0.02$ less than 0.05$)$ for the $30 \mathrm{~mm}$ grid.

Regardless of the type of grid, the amount of shrimp sorted per minute is larger for the experimental trawl; and this amount increases with the spacing of the grid (Figure 5).

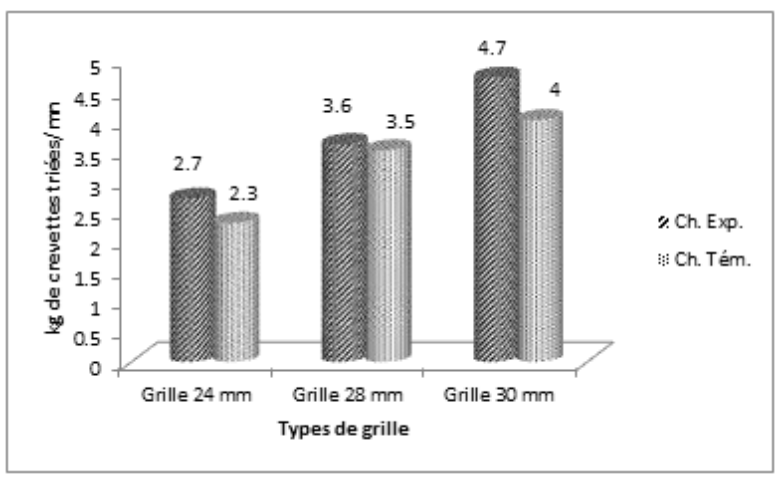

Figure 5. Duration of sorting of gamba shrimp caught by control and experimental trawls during tests with Nordmore grids of 24, 28 and 30 mm spacings.

\section{Discussion}

Senegal's deep demersal resources include many species of crustaceans, fish and marine molluscs. These species live at average depths between 150 and $1000 \mathrm{~m}$ where they are almost exclusively exploited by shrimpers, vessels targeting hake and some rare crabbers (Thiam and Fall, 2010). Deep-sea shrimp fisheries, which are not very selective, generate large discards and by-catches usually composed of crustaceans, fish and molluscs of different size classes.

The effectiveness of the Nordmore Grid was evaluated on the basis of 2 criteria (percentage of gamba shrimp losses and by-catch species rejection) and tests conducted outside the gamba shrimp abundance period.

The average ratio of bycatch / catch of gamba shrimp ranged from $9 / 1$ (control trawl) to 5/1 (experimental trawl) with an average of $7 / 1$. This average ratio observed here is close to the ratio $(8 / 1)$ observed by Caverivière \& Rabarison (1988) for the coastal shrimp Penaeus notialis in Senegal. It also compares the ratio observed in Mauritanian waters, with an average ratio of 7.5 / 1 (Diop et al., 2002). With the $30 \mathrm{~mm}$ grid, the experimental trawl showed a ratio around $2.2 / 1$, almost equal to that $(2 / 1)$ observed by Thiam and Fall (2010) and Thiam et al. 2014 for the same species in the same Senegalese waters. On a worldwide scale, this result is similar to that of Siebenaler (1952) carried out in the subtropical zone (Tortugas) with a ratio $=$ $2 / 1$, of Compton (1962) carried out in the tropical zone (Texas) with a ratio of $2.5 / 1$, Bryan (1980) made in the same area with a ratio varying from 1.5 to 3 and Large Soto (1981) made in low California with a ratio of the order of $2.3 / 1$.

The $24 \mathrm{~mm}$ and $28 \mathrm{~mm}$ grids are characterized by large variations in percent loss results of gamba shrimp. In fact, the former rejected $18 \%$ of shrimp on average, with minimum and maximum values of 10 and $43 \%$ respectively. The second had an average rejection of $16 \%$ and minimum and maximum values of 3 and $27 \%$, respectively. On the other hand, the $30 \mathrm{~mm}$ grid stands out because of the lower variability observed. This grid generated an average gamba loss rate of $8 \%$ and minimum and maximum values of $3 \%$ and $20 \%$, respectively.

A number of factors may explain the high variability in shrimp losses observed for $24 \mathrm{~mm}$ and $28 \mathrm{~mm}$ grids. One of the main factors is the speed of water in the trawl that depends on the speed of trawling. During the sea trials, the trawl speed ranged from 2.5 to more than 3 knots, which is much too high a speed to allow optimal operation of the Nordmore grid which has been developed for a fishery generally between 1.8 to 2.5 knots maximum (Isaksen et al 1992, Seychelles et al., 2010). It should be noted that the same trawling speeds were applied to all grids. Thus, the low variability observed with the $30 \mathrm{~mm}$ grid could be explained by a much larger spacing allowing the shrimp to pass through the grid without major constraint

Regardless of the type of spacing, commercial species such as broth (Brotula barbata) and St. Peter's (Zenopsis conchifer) are removed by the grid. Other non-commercial species that play a very important role in marine food webs, such as Centrolophus niger, Centrophorus uyato, Epigonus telescopus, Hypoclidonia bella, Paramola cuvieri, Setarches guntheri, Sphoeroides pachygaster are also 100\% eliminated by the Nordmore grid. . On the other hand, the percentages of elimination lower than $100 \%$ are explained by the presence of individuals of small sizes (equal to or lower than the spacing of the bars of the grid). In theory, a fish one meter in length can reach a maximum speed of 10 times the length of his body for a very short period of time, of the order of a second (Bainbridge, 1958). As a result, bycatch of $15.4 \mathrm{~cm}$ in length can only theoretically reach a maximum speed of $1.54 \mathrm{~m} \mathrm{~s}-1$, or about 3 knots maximum for a very short time. In addition, this maximum speed is rarely reached because it depends on environmental factors (temperature, speed and direction of flow) and physiological factors (muscle fiber composition and muscle contraction time). A study (Beamish, 1978), conducted on more than 40 species of fish, showed that most individuals 5 to $15 \mathrm{~cm}$ in length could not maintain more than 10 minutes their normal cruising speed. Thus, the trawling speeds observed during the experiments are 
close to the maximum swimming speeds of small-sized non-target fish species and are well above their normal cruising speed. Reduced speed can therefore significantly increase the escape of non-target fish (Grimaldo, 2006)

Compared to the shrimp sorting time, for the grids of 24 $\mathrm{mm}$ and $28 \mathrm{~mm}$, no significant difference in sorting speed was observed. However, in all cases, a saving of time is noted with the experimental trawl. On the other hand, for the $30 \mathrm{~mm}$ grid, a significant difference in sorting speed is noted between the control trawl and the experimental trawl. The sailors sorted $4.7 \mathrm{~kg} / \mathrm{min}$ for the experimental trawl versus $4 \mathrm{~kg} / \mathrm{min}$ for the control trawl. In addition to this quantitative data, from a qualitative point of view, the sailors assigned to sorting noted better comfort in sorting the experimental trawl catches.

\section{Conclusions and Recommendations}

Regardless of the spacing ( $24 \mathrm{~mm}, 28 \mathrm{~mm}$ or $30 \mathrm{~mm}$ ), the Nordmore grid completely removed large individuals of several species of commercial interest (John dory and Bearded brotula) or not (rays, sharks, etc.). However, the problem of selectivity persists with small individuals (size smaller than the maximum size of gamba shrimp).

For some fishing locations, benthic crustaceans (Munidae), sometimes very abundant, could clog the bars of the Nordmore grid, preventing shrimp from passing through the . grid It would be interesting to remove the scraper chain that would raise these crustaceans from the bottom.

The $30 \mathrm{~mm}$ grid stands out with percentages of gamba shrimp losses ranging from 3 to $20 \%$ with an average of $8 \%$; and a ratio of bycatch / gamba shrimp catch around 2.2 / 1, below the world average for this type of fishery $(5 / 1)$. For this purpose, it is recommended to conduct another test session with the Nordmore $30 \mathrm{~mm}$ spacing grid taking into account the following guidelines

- Check fishing gear adjustments (adjustments, weights and buoyancy) and bring bottom contact to a point where the catch of small crustaceans and small flatfish is reduced without affecting the shrimp yield.

- Reflect on the possibility of using a bottomless trawl (Topless) that would facilitate the top escape of some groundfish considering the small vertical trawl opening.

- Modify the trawl rear part to correctly fit the Nordmore device.

- Install a longer extension section at the back of the grill to keep the codend away from the grill.

- $\quad$ Redraw a new grid that would be wider and lower (1.6 $\mathrm{m}$ wide $\mathrm{x} 0.95 \mathrm{~m}$ high) that could accommodate this type of trawl that has a small vertical opening.

- Study the possibility of using an underwater camera during a subsequent mission to collect images on the behavior of the machine and the selectivity system

\section{REFERENCES}

[1] D. L. Alverson, M. H. Freeberg, S. A. Murawski, \& . J. G. Pope. A global assessment of fisheries by-catch and discards. FAO Fisheries Technical Paper. Rome, FAO. No. 339, 233 pp, 1994.

[2] E. E. Ambrose, B. B. Solarin,, C. E. Isebor, A. B. Williams. Assessment of fish by-catch species from coastal artisanal shrimp beam trawl fisheries in Nigeria. Fisheries Research $71,125-132,2005$.

[3] E. E. Ambrose, P. E. Lebo. Evaluations of nordmore grid by-catch reduction device (BRD) in nearshore shrimp beam trawl fisheries, Nigeria. Journal of Aquatic Sciences, 24(1), 30-39, 2009.

[4] F. W. H. Beamish. Swimming capacity. Fish Physiology. Hoar, W. S. \& Randall, D. J. New York, Academic Press, VII, Locomotion, 101-187, 1978.

[5] M. K.. Broadhurst. Modifications to reduce by-catch in prawn trawls: a review and framework for development. Rev. Fish Biol. Fish. 10, 27-60, 2000.

[6] C.E. Bryan. Organisms captured by the commercial shrimp fleet on Texas brown shrimps (Penaeus aztecus Ives) grounds. Thesis. Corpus Chisti State University. Division of Biology, Corpus Chisti, Texas, 44 pp, 1980.

[7] A. Caverivière, G.A Rabarison,. Captures accessoires et rejets de la pêche crevettière à Penaeus notialis au Sénégal ». Doc. Scient. Oceanogr. Dakar-Thiaroye, n¹11, 1998.

[8] H.Compton,. Survey of the commercial shrimps and associated organisms of Gulf Area 20. Texas Game Fish. Comm. Mar. Fich. Div. Repts, 19 pp, 1962.

[9] S. Faye. Le système d'upwelling des canaries: mesure et modélisation des variations saisonnières de la circulation et des temperatures de surface. PhD Thesis. UCAD-ISRA/CRODT, 184 pp, 2015.

[10] W. M. Hickey, G.Brothers, D. L. Boulos. By-catch reduction in the northern shrimp fishery. Canadian Technical Report in Fisheries and Aquatic Sciences, 41 pp. 1993.

[11] B. Isaksen, J. W.Valdemarsen, R. B. Larsen, L.Karlsen. Reduction of fish by-catch in shrimp trawl using a rigid separator grid in the aft belly. Fisheries Research, 13, 335-352, 1992.

[12] R Gillet. Global study of shrimp fisheries. FAO Document technique sur les pêches. Rome, FAO. No. 475: 331pp, 2008.

[13] E.Grimaldo. The effects of grid angle on a modified Nordmøre-grid in the nordic shrimp fishery. Fisheries Research, 77, 53-59, 2006.

[14] FAO. La situation mondiale des pêches et de l'aquaculture, Rome, 2009.

[15] B. Isaksen, J. W. Valdemarsen, R. B. Larsen, L. Karlsen. Reduction of fish by-catch in shrimp trawl using a rigid separator grid in the aft belly. Fisheries Research, 13, 
$335-352,1992$

[16] K. Kelleher..Discards in the world's marine fisheries, Rome, FAO, 22 pp, 2005

[17] J.C. Large-Soto. Integration approaches of the shrimp fishery, Univ. Auton. Baja Calif. Sur. no 5, 47 pp, 1981.

[18] S. Ndoye, X. Capet, P. Estrade, D. Dagorne, B. A. Sow, A. Lazar, A. Gaye, P. Brehmer. Sea Surface temperature 'SST' patterns and dynamics of the Southern Senegal-Gambia upwelling center. Journal of Geophysical Research Oceans, 119, 8315-8335, 2014.

[19] S. Pascoe, A. Revill. Costs and Benefits of Bycatch Reduction Devices in European Brown Shrimp Trawl. Fisheries Environmental and Resource Economics, 27 (1), 43-64, 2004.

[20] A. D..Pettovello. By-catch in the Patagonian red shrimp (Pleoticus muelleri) fishery. Marine Freshwater Resources, 50, 123-127, 1999.

[21] Y. Plourde, B. Faye, N .Thiam. Essais de la grille Nordmore sur un chalutier commercial du Sénégal. Rapport technique, ADUPES, 11 pp. 2015.

[22] L. Seychelles, N.Thiam, Y. Plourde. Test de la grille Nordmore en pêche commerciale de la gamba au Sénégal. Rapport final. DPM/CRODT/COLLEGIA, 45 p, 2010.

[23] J.B. Siebenaler,.- Studies of « Trash » caught by shrimp trawlers in Florida. Proc. Gulf Carib. Fish. Inst, 4, 94, 1952.
[24] C.N.S. Silva, K. Matt, H. José Dias, P. André Cattani, L. H. Spach. The effects of Nordmøre-grid bar spacings on catches in a Brazilian artisanal shrimp fishery. Fisheries Research, 127-128, 188-193, 2012.

[25] N. Thiam.. Rapport sur l'expérimentation de la grille sélective Nordmore dans les pêcheries crevettières dans la ZEE de la République Islamique de Mauritanie. IMROP/IMARES/EPAQ/CRODT, 19 pp, 2008.

[26] N. Thiam. Rapport d'étape 1 de l'échantillonnage biologique à bord des crevettiers profonds sénégalais. Document interne du CRODT/DPM/AFD, 24 pp, 2009.

[27] N.Thiam, M. Fall. Prises accessoires des pêcheries crevettières profondes au Sénégal: variations nycthémérales et saisonnières des captures. J. Sci. Hal. Aquat., 1, 49-54, 2010.

[28] N.Thiam, M. Fall, M. Thiaw. Echantillonnage biologique à bord des crevettiers profonds operant au large du Sénégal. Rapport final, 31 pp, 2014.

[29] M. Thiaw. Dynamique des ressources halieutiques à durée de vie courte: cas des stocks de poulpe et de crevettes exploités au Sénégal. Thèse pour l'obtention du Diplôme de docteur de l'Agrocampus Ouest, mention Halieutique, Rennes, France, 228 pp, 2010.

[30] J. H. Zar. Biostatistical analysis. New Jersey, Prentice Hall, 1999. 